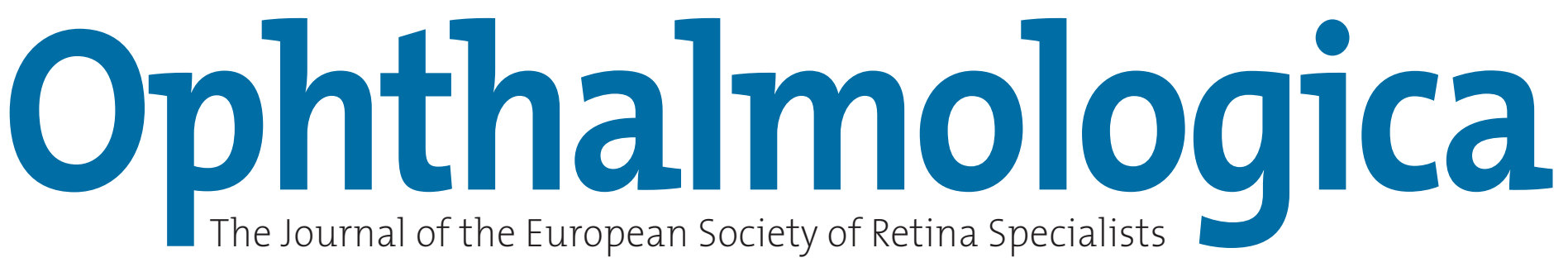

\title{
EURETINA
}

European Society of Retina Specialists

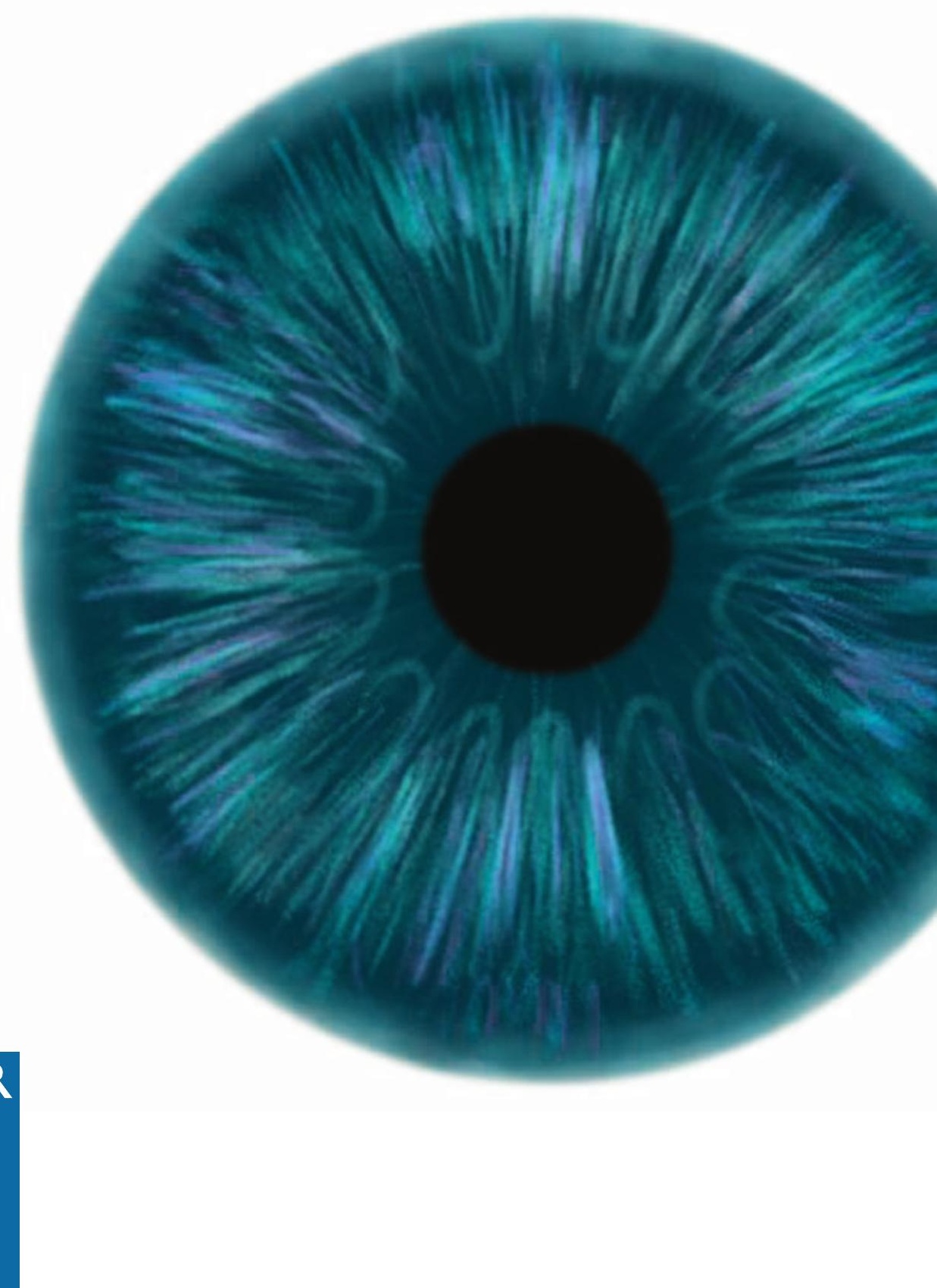




\section{An essential update on uveal melanoma therapy}

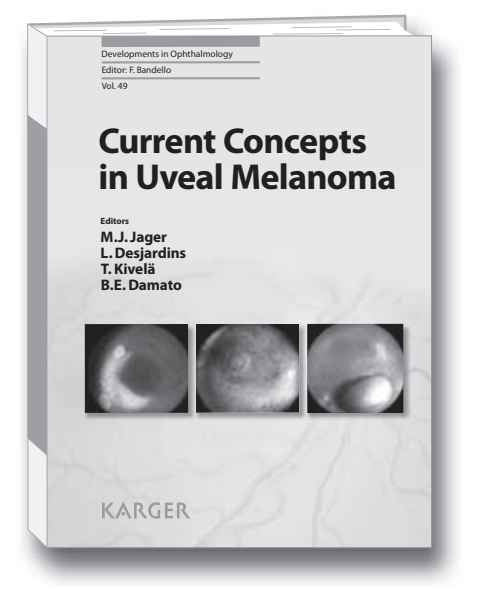

Uveal melanoma is an aggressive form of cancer that can involve the iris, the ciliary body, and/or the choroid, which is the main location of this tumor. Patients often wish to be informed about treatment choices and the results of different approaches. Important current clinical questions are whether a biopsy should be taken of choroidal melanomas, what should be done with this biopsy, and whether high-risk patients should be screened regularly.

This volume describes the clinical characteristics of uveal melanoma along with the different current techniques available for treatment, such as radioactive plaque treatment, proton beam therapy, and local tumor resection. Furthermore, techniques for taking biopsies and characterizing biopsy material are demonstrated. Future therapies such as anti-VEGF treatment and options for the treatment of metastases are also discussed.

Residents with an interest in ocular oncology, ophthalmologists or physicians dealing with uveal melanoma, as well as patients wishing to know more about this malignancy will find a topical update on uveal melanoma in this publication.

\section{Current Concepts in Uveal Melanoma}

Editors

Martine J. Jager

Laurence Desjardins

Tero Kivelä

Bertil E. Damato

\section{Contents}

Preface: Jager, M.J.; Desjardins, L.; Kivelä, T.; Damato, B.E.

Diagnosis of Uveal Melanoma: Kivelä, $\boldsymbol{T}$. Treatment Selection for Uveal Melanoma: Damato, B.E.

Ruthenium-106 Brachytherapy: Pe'er, J. Treatment of Uveal Melanoma by

Accelerated Proton Beam: Desjardins, L.; Lumbroso-Le Rouic, L.; Levy-Gabriel, C.; Cassoux, N.; Dendale, R.; Mazal, A.; Delacroix, S.; Sastre, X.; Plancher, C.; Asselain, $B$.

Stereotactic Photon Beam Irradiation of Uveal Melanoma: Zehetmayer, $\boldsymbol{M}$.

Local Resection of Uveal Melanoma: Damato, B.E.

Biopsies in Uveal Melanoma: Midena, E.; Parrozzani, $R$.
Analysis of Intraocular Biopsies: Coupland, S.E. Antiangiogenic Therapy in Uveal Melanoma: el Filali, M.; van der Velden, P.A.; Luyten, G.P.M.; Jager, M.J.

Immunotherapy of Uveal Melanoma: Bosch, J.J.

Genetic Determinants of Uveal Melanoma: Couturier, J.; Saule, $\mathbf{S}$.

Therapeutic Options in Metastatic Uveal Melanoma: Mariani, P.; Servois, V.; Piperno-Neumann, $S$.

www.karger.com/deoph

Developments in Ophthalmology, Vol. 49 Series Editor: Bandelo, F. (Milan) ISSN 0250-3751 / e-ISSN 1662-2790

Current Concepts in Uveal Melanoma Editors: Jager, M.J. (Leiden); Desjardins, L. (Paris); Kivelä, T. (Helsinki); Damato, B. (Liverpool) VIII + 186 p., 37 fig., 23 in color, 12 tab., hard cover, 2012

CHF 224.- / EUR 187.- / USD 264.00

Prices subject to change

EUR price for Germany, USD price for USA only ISBN 978-3-8055-9790-6 e-ISBN 978-3-8055-9791-3

\section{Please send: _ _ copy/ies}

Postage and handling free with prepayment

$\varepsilon$ Payment:

Please charge to my credit card

- $\square$ American Express $\square$ Diners $\square$ Eurocard

ᄂ $\square$ MasterCard $\square$ Visa

Card No.:

Exp. date:

- CVV/CVC

(3 digits in the signature field on the back of Visa and MasterCard)

$\square$ Check enclosed $\quad \square$ Please bill me

Orders may be placed with any bookshop, subscription agency, directly with the publisher or through a Karger distributor.
Fax: +41613061234

S. Karger AG, P.O. Box, CH-4009 Basel (Switzerland)

E-Mail orders@karger.ch, www.karger.com

Name/Address: 


\section{Ophthalmologica}

\section{International Journal of Ophthalmology}

Founded 1899 as 'Zeitschrift für Augenheilkunde' by H. Kuhnt and J. von Michel Continued by J. Meller (1923-1938), C. Behr (1925-1938), A. Brückner (1938-1959), H.J.M. Weve (1938-1962), H.M. Dekking (1954-1966), J. ten Doesschate (1967-1971), J. François (1959-1979), E.B. Streiff (1954-1979), H. Sautter (1979-1984), W. Straub (1979-1993), Ch. Ohrloff (1994-2009)

\section{Editor}

\section{J. Cunha-Vaz, Coimbra}

\section{Associate Editors}

G.W. Aylward, London

J. Bainbridge, London

F. Bandello, Milan

R. Belfort Jr., São Paulo

G. Coscas, Créteil

J.C.N. Murta, Coimbra

R.J. Olson, Salt Lake City, Utah

N. Pfeiffer, Mainz

G. Richard, Hamburg

S. Wolf, Bern

\section{Editorial Board}

J.F. Abreu, Coimbra

J.L. Alió, Alicante

D. Balasubramanian, Hyderabad

R. Bernardes, Coimbra

A.J. Bron, Oxford

V. Chong, Oxford

B. Corcóstegui, Barcelona

A. Cruess, Halifax, N.S.

R. Dana, Boston, Mass.

A. Gaudric, Paris

F. Holz, Bonn

Y.N. Hui, Xian

J.B. Jonas, Mannheim

P. Kestelyn, Gent

P.T. Khaw, London

I.K. Kim, Boston, Mass.

T. Kohnen, Frankfurt

C. Lobo, Coimbra

A. Loewenstein, Tel Aviv

B. Lorenz, Giessen

P. Massin, Paris
E. Midena, Padova

A. Negi, Kobe

Y. Ogura, Nagoya

J.C. Pastor Jimeno, Valladolid

U. Pleyer, Berlin

L. Rossetti, Milan

J.A. Sahel, Paris

U. Schmidt-Erfurth, Vienna

R. Silva, Coimbra

E. Stefánsson, Reykjavík

M.J. Tassignon, Antwerp

K. Tsubota, Tokyo

A. Tufail, London

M. Ulbig, Munich

P. Wiedemann, Leipzig

D. Wong, Liverpool

T.Y. Wong, Singapore

$\mathrm{X}$. Xu, Xangai

T. Zeyen, Louvain

L. Zografos, Lausanne

E. Zrenner, Tübingen
Printed in Switzerland on acid-free and non-aging paper (ISO 9706) by Reinhardt Druck, Basel
Appears bimonthly: 1 volume per year (6 issues) 


\section{Ophthalmologica}

\section{Submission}

Original papers, reviews and carefully selected case reports written in English are considered for publication. Manuscripts should be submitted online

\section{www.karger.com/oph}

Should you experience any problems with your submission, please contact the Editorial Office at:

\author{
oph@karger.ch \\ Prof. J. Cunha-Vaz \\ S. Karger AG \\ Editorial Office 'Ophthalmologica' \\ PO Box \\ $\mathrm{CH}-4009$ Basel (Switzerland) \\ Fax +4161306 1434
}

\section{Conditions}

All manuscripts are subject to editorial review. Manuscripts are received with the explicit understanding that they are not under simultaneous consideration by any other publication. A cover letter with the name, address, and telephone and telefax numbers of the corresponding author must accompany each manuscript. This letter must include a statement that affirms that all authors concur with the submission. Submission of an article for publication implies transfer of the copyright from the author to the publisher upon acceptance. Accepted papers become the permanent property of 'Ophthalmologica' and may not be reproduced by any means, in whole or in part, without the written consent of the publisher. It is the author's responsibility to obtain permission to reproduce illustrations, tables, etc. from other publications.

\section{Conflicts of Interest}

Authors are required to disclose any sponsorship or funding arrangements relating to their research and all authors should disclose any possible conflicts of interest. Conflict of interest statements will be published at the end of the article.

\section{Types of Papers}

Editorial

EURETINA - Review

EURETINA - Original Paper

Original Paper

Review

New Technologies in Ophthalmology

Letter to the Editor

Reviews are either invited, or may be submitted for consideration. Invited reviews, if accepted, are not subject to page charges. The recommended length is 6 printed pages (approx. 15 double-spaced manuscript pages).

Mini Reviews should contain an easy-to-read literature overview on a specific topic. Papers are either invited or may be submitted for consideration. Only concise articles of no more than 2 printed pages (approx. 6 doublespaced manuscript pages), including an abstract of max. 200 words and references, will be accepted. Please submit your mini review online.

\section{Letter to the Editor}

Letters are only accepted if they directly concern articles previously published in this journal and clinical subjects related to the matters discussed. The editor reserves the right to submit copies of such letters to the authors of the articles concerned prior to publication in order to permit them to respond in the same issue of the journal. Letters should have a maximum of one printed page (350-420 words, up to 8 references).

\section{Arrangement}

Title page: The first page of each paper should indicate the title, the authors' names, the institute where the work was conducted, and a short title for use as running head.

Full address: The exact postal address of the corresponding author complete with postal code must be given at the bottom of the title page. Please also supply phone and fax numbers, as well as e-mail address.

Key words: Please supply 3-10 key words in English that reflect the content of the paper.

Abstract: Each paper needs an abstract in English of not more than $\mathbf{1 5 0}$ words. The abstract is of utmost importance. It should contain the following information: purpose of the study, procedures, results, conclusions and message of the paper.

\section{Footnotes: Avoid footnotes.}

Tables and illustrations: Tables and illustrations (both numbered in Arabic numerals) should be sent in separate files. Tables require a heading and figures a legend, also in a separate file. Due to technical reasons, figures with a screen background should not be submitted. When possible, group several illustrations in one block for reproduction (max. size $180 \times 223 \mathrm{~mm}$ ). Black and white half-tone and color illustrations must have a final resolution of $300 \mathrm{dpi}$ after scaling, line drawings one of $800-1,200 \mathrm{dpi}$.

\section{Color illustrations}

Online edition: Color illustrations are reproduced free of charge. In the print version, the illustrations are reproduced in black and white. Please avoid referring to the colors in the text and figure legends.

Print edition: Up to 6 color illustrations per page can be integrated within the text at CHF 800.- per page.

References: In the text identify references by Arabic numerals [in square brackets]. Material submitted for publication but not yet accepted should be noted as 'unpublished data' and not be included in the reference list. The list of references should include only those publications which are cited in the text. Do not alphabetize; number references in the order in which they are first mentioned in the text. The surnames of the authors followed by initials should be given. There should be no punctuation other than a comma to separate the authors. Preferably, please cite all authors. Abbreviate journal names according to the Index Medicus system. Also see International Committee of Medical Journal Editors: Uniform requirements for manuscripts submitted to biomedical journals (www.icmje.org).

Examples

(a) Papers published in periodicals: Chatel J-M, Bernard $\mathrm{H}$, Orson $\mathrm{FM}$ : Isolation and characterization of two complete Ara h 2 isoforms cDNA. Int Arch Allergy Immunol 2003;131:14-18.

(b) Papers published only with DOI numbers:

Theoharides TC, Boucher W, Spear K: Serum interleukin-6 reflects disease severity and osteoporosis in mastocytosis patients. Int Arch Allergy Immunol DOI: 10.1159/000063858.

(c) Monographs: Matthews DE, Farewell VT: Using and Understanding Medical Statistics, ed 3, revised. Basel, Karger, 1996.(d) Edited books: DuBois RN: Cyclooxygenase-2 and colorectal cancer; in Dannenberg AJ, Dubois RN (eds): COX-2. Prog Exp Tum Res. Basel, Karger, 2003, vol 37, pp $124-137$.

Reference Management Software: Use of EndNote is recommended for easy management and formatting of citations and reference lists.

\section{Digital Object Identifier (DOI)}

S. Karger Publishers supports DOIs as unique identifier for articles. A DOI number will be printed on the title page of each article. DOIs can be useful in the future for identifying and citing articles published online without volume or issue information. More information can be found at www.doi.org.

\section{Supplementary Material}

Supplementary material is restricted to additional data that are not necessary for the scientific integrity and conclusions of the paper. Please note that all supplementary files will undergo editorial review and should be submitted together with the original manuscript. The Editors reserve the right to limit the scope and length of the supplementary material. Supplementary material must meet production quality standards for Web publication without the need for any modification or editing. In general, supplementary files should not exceed $10 \mathrm{MB}$ in size. All figures and tables should have titles and legends and all files should be supplied separately and named clearly. Acceptable files and formats are: Word or PDF files, Excel spreadsheets (only if the data cannot be converted properly to a PDF file), and video files (.mov, .avi, .mpeg).

\section{Author's Choice'}

Karger's Author's Choice ${ }^{\mathrm{TM}}$ service broadens the reach of your article and gives all users worldwide free and full access for reading, downloading and printing at www. Karger.com. The option is available for a one-time fee of CHF 3000.-, which is a permissible cost in grant allocation. More information can be found at www.karger.com/ authors_choice.

\section{NIH-Funded Research}

The U.S. National Institutes of Health (NIH) mandates under the NIH Public Access Policy that final, peer-reviewed manuscripts appear in its digital database within 12 months of the official publication date. As a service to authors, Karger submits the final version of your article on your behalf to PubMed Central. For those selecting our premium Author's Choice ${ }^{\mathrm{TM}}$ service, we will send your article immediately upon publishing, accelerating the accessibility of your work without the usual embargo. More details on NIH's Public Access Policy is available at http://publicaccess.nih.gov/policy.htm

\section{Self-Archiving}

Karger permits authors to archive their pre-prints (i.e. prerefereeing) or post-prints (i.e. final draft post-refereeing) on their personal or institution's servers, provided the following conditions are met: Articles may not be used for commercial purposes, must be linked to the publisher's version, and must acknowledge the publisher's copyright. Authors selecting Karger's Author's Choice ${ }^{\mathrm{TM}}$ feature, however, are also permitted to archive the final, published version of their article, which includes copyediting and design improvements as well as citation links.

\section{Page Charges}

There are no page charges for papers of 3 or fewer printed pages (including tables, illustrations and references). Each additional complete or partial page is charged to the author at CHF 325.-. The allotted size of a paper is equal to approx. 8 manuscript pages (including tables, illustrations and references).

\section{Proofs}

Unless indicated otherwise, proofs are sent to the corresponding author and should be returned with the least possible delay. Alterations other than the correction of printer's errors are charged to the author.

\section{Reprints}

Order forms and a price list are sent with the proofs. Orders submitted after the issue is printed are subject to considerably higher prices.

\section{KARGER}

Fax +4161306 1234 E-Mail karger@karger.ch www.karger.com 


\section{Ophthalmologica}

ISSN Print Edition: 0030-3755

ISSN Online Edition: 1423-0267

Journal Homepage: www.karger.com/oph

Publication Data: 'Ophthalmologica' is published 8 times a year. Volumes 227 and 228, each with 4 issues, appear in 2012.

Copyright: (c) 2012 S. Karger AG, Basel (Switzerland). All rights reserved. No part of this publication may be translated into other languages, reproduced or utilized in any form or by any means, electronic or mechanical, including photocopying, recording, microcopying, or by any information storage and retrieval system, without permission in writing from the publisher or, in the case of photocopying, direct payment of a specified fee to the Copyright Clearance Center.

Disclaimer: The statements, opinions and data contained in this publication are solely those of the individual authors and contributors and not of the publisher and the editor(s). The appearance of advertisements in the journal is not a warranty, endorsement, or approval of the products or services advertised or of their effectiveness, quality or safety. The publisher and the editor(s) disclaim responsibility for any injury to persons or property resulting from any ideas, methods, instructions or products referred to in the content or advertisements.
Subscription Rates: Subscriptions run for a full calendar year. Prices are given per year. Personal subscription:

Print or Online

CHF 970.-

EUR 776.-

USD 942.00

Print+Online combined CHF 1066.-

EUR 852.-

USD 1036.00

postage and handling (added to print and print+online)

CHF 54.40 Europe, CHF 80.- Overseas

EUR 41.60

USD 75.20

Institutional subscription

Print or Onlin

Print+Online combined

CHF 1938.-

EUR 1550.-

CHF 2132.-

USD 1882.00

EUR 1706.-

postage and handling (added to print and print+online)

CHF 68.- Europe, CHF 100.- Overseas

EUR 52.-

USD 94.00

Airmail surcharge: CHF 68.- / USD 64.00

Discount subscription prices:

- Association for Research and Vision in

Ophthalmology (ARVO)

- EVER

- EURETINA

- and other related societies
Back Volumes and Single Issues: Information on availability and prices of single print issues and print or electronic back volumes can be obtained from Customer Service at service@karger.ch.

Bibliographic Indices: This journal is regularly listed in bibliographic services, including Current Contents ${ }^{\circledR}$ and PubMed/MEDLINE.

Photocopying: This journal has been registered with the Copyright Clearance Center (CCC), as indicated by the code appearing on the first page of each article. For readers in the US, this code signals consent for copying of articles for personal or internal use, or for the personal or internal use of specific clients, provided that the stated fee is paid per copy directly to

Copyright Clearance Center Inc.

222 Rosewood Drive

Danvers, MA 01923 (USA)

A copy of the first page of the article must accompany payment. Consent does not extend to copying for general distribution, for promotion, for creating new works, or for resale. In these cases, specific written permission must be obtained from the copyright owner,

S. Karger AG, P.O. Box

CH-4009 Basel (Switzerland).
Subscription Orders:

Orders can be placed at agencies, bookstores, directly with the Publisher

\section{S. Karger AG}

Medical and Scientific Publishers

P.O. Box

CH-4009 Basel

Switzerland

(for courier services only:

Allschwilerstrasse 10

CH-4055 Basel)

t: +416130611 11

f: +41613061234

e: karger@karger.ch

w: www.karger.com or further Karger offices

or representatives:

Germany

S. Karger GmbH

Postfach

79095 Freiburg

Deutschland

(Hausadresse: Wilhelmstrasse 20A,

79098 Freiburg)

t: +49761452070

f: +497614520714

e: information@karger.de

w: www.karger.de

Japan

Karger Japan, Inc.

Shiba Daimon Asahi Bldg. 2F

1-2-23 Shiba Daimon

Minato-ku

Tokyo 105-0012

Japan

t: +81364356242

f: +81364356244

e: publisher@karger.jp

w: www.karger.jp

Change of Address:

Both old and new address should be sent

to the subscription source.

USA

S. Karger Publishers, Inc.

26 West Avon Road

P.O. Box 529

Unionville, CT 06085

USA

Toll free: +18008285479

t: +18606757834

f: +18606757302

e: karger@snet.net

France

Librairie Médi-Sciences Sar

36, bd de Latour-Maubourg

75007 Paris

France

t: $+33(0) 145514258$

f: $+33(0) 145560780$

f: $+33(0) 145560780$

e: librairie@medi-sciences.

Gulf Council Countries, Iran,

Middle East, North Africa, Turkey

Trans Middle East International

Distribution Co. Ltd.

KaSha

134 Queen Rania Al Abdullah Street

Jordan Trade Center Bldg. 3rd Floor

P.O. Box 2376

Amman 11953

Jordan

t: +96265153467

f: +96265153472

e: info@kasha.cc

w: www.KaShaonline.com
South East Asia, China and Taiwan Karger Regional Office (Malaysia)

CEO Suite Kuala Lumpur

Quill 7, 27th Floor

Jalan Stesen Sentral 5

KL Sentral

Kuala Lumpur 50470

Malaysia

t: +60327766803

f: +60327766999

e: service@karger.cn; r.chew@karger.cn

Karger China

10th Floor, Twin Towers (East)

B12 Jianguomenwai Avenue

Beijing 100022

China

t: +861051235033

f: +861051235122

e: service@karger.cn; r.chew@karger.cn

w: www.karger.cn

India, Bangladesh, Sri Lanka

Medscience India

Plot No. 17, Yusuf Sarai Market

B.L. Glass Building, 2nd Floor

Sri Aurobindo Marg

New Delhi 110016

India

t: +91 1146029633

f: +911146029634

c: +919891052128

e: medsci.india@gmail.com

\section{KARGER}

Fax +41 613061234

E-Mail karger@karger.ch

www.karger.com
(C) 2012 S. Karger AG, Basel

The Journal Home Page is available at:

www.karger.com/oph 


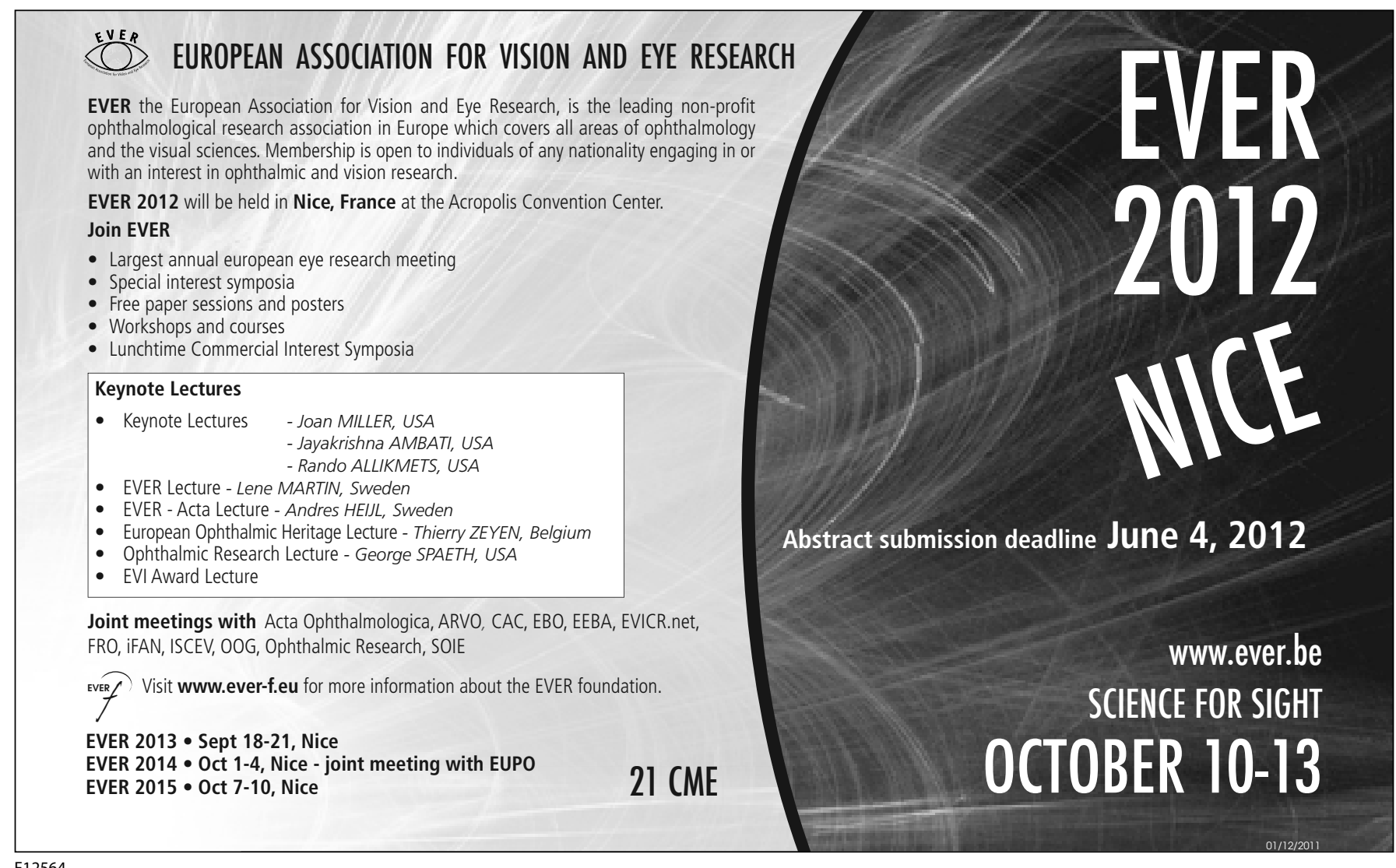

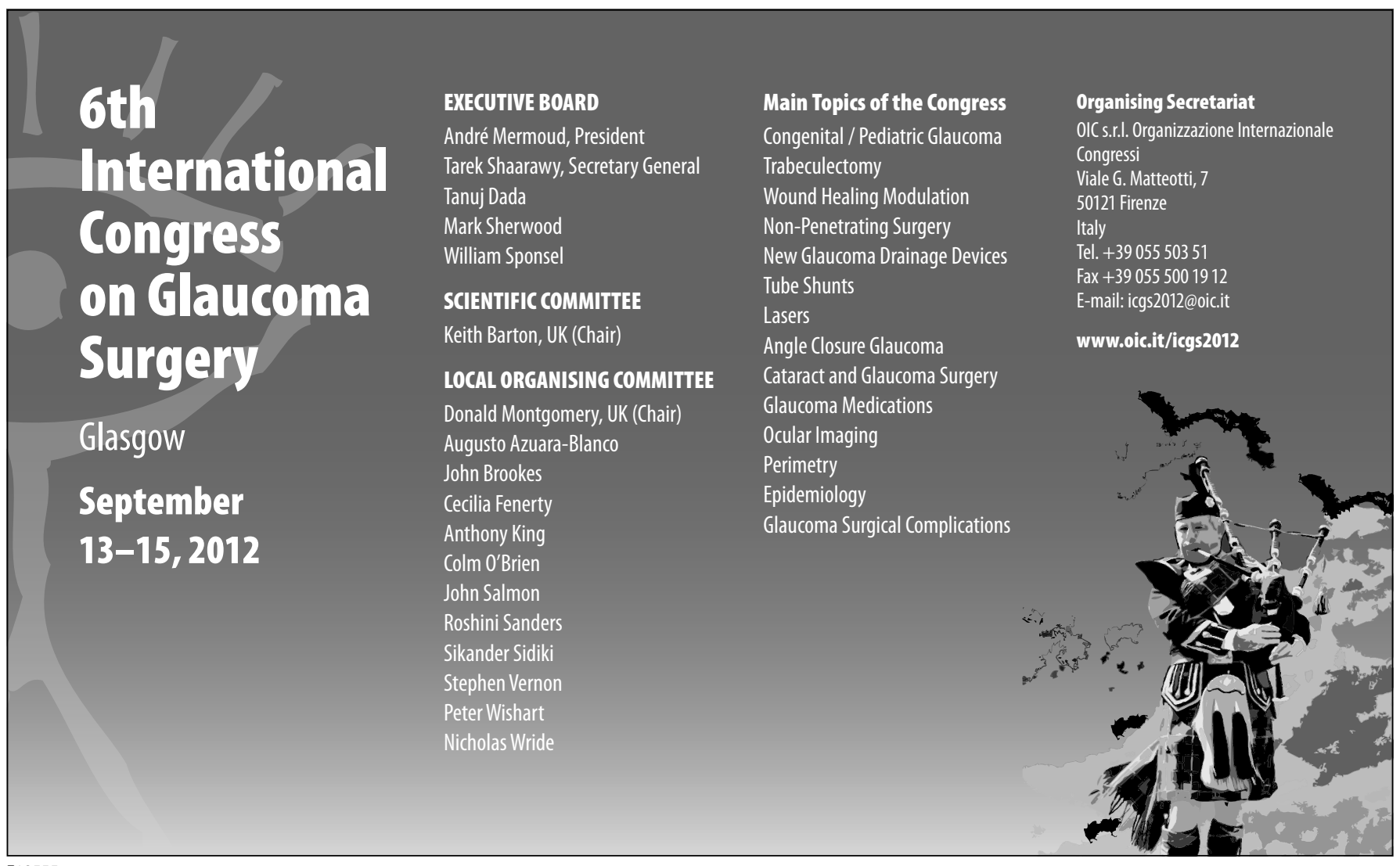


The Orbital Society hosts a meeting only every 5 years, where everyone in the world is invited to learn and share ideas about orbital disease and surgery. We want this to be a very special meeting for you. This is an exclusive opportunity for experts to share their latest findings, technical expertise and experiences in the field. The scientific program provides a unique platform for presentations and discussion on new ideas, controversial topics about old subjects that are yet to be resolved and poster presentations.

The Sociedad Iberoamericana de Oculoplástica is the main Spanish speaking oculoplastic society, uniting specialists from Mexico, Central America, South America, Portugal and Spain. It hosts a meeting every 2 years. The 3rd meeting will take place preceding the 3rd Orbital Society Meeting. Simultaneous translation to English will be available.

We hope to see you in Buenos Aires 2012!

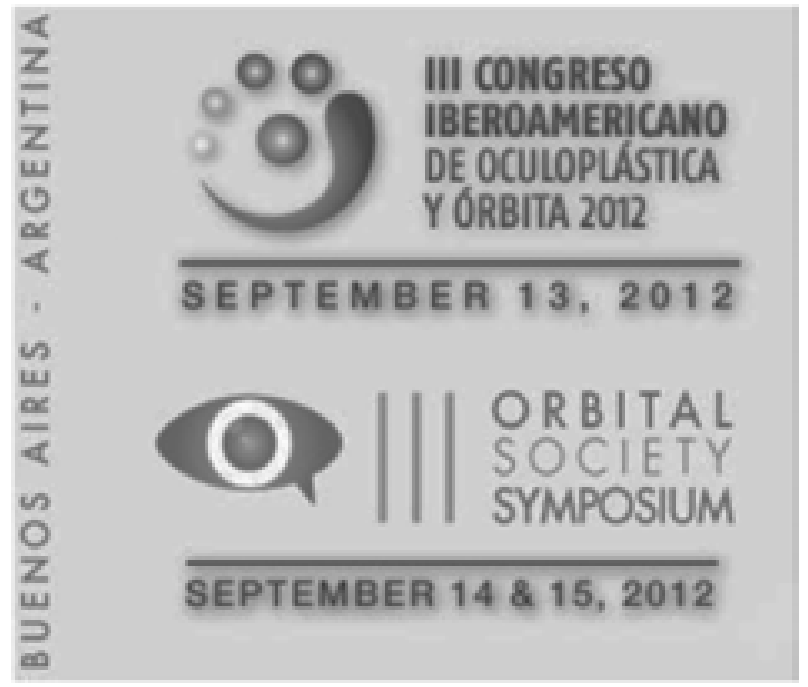

\section{'A collection of extraordinary essays'}

\section{GOTTFRIEDSCHATZ}

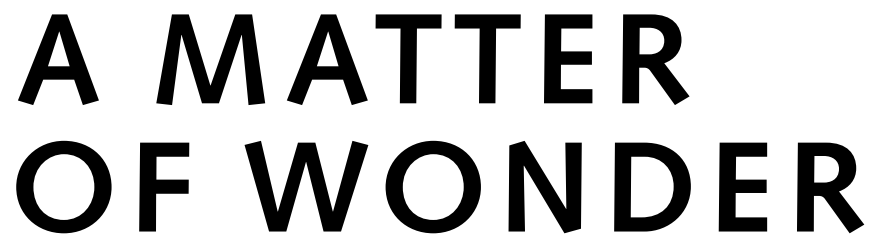

What Biology Reveals about Us, Our World, and Our Dreams

Where do we come from? Is our destiny determined by the genes we inherit? In this book Gottfried Schatz, the world-renowned biochemist and co-discoverer of mitochondrial DNA, gives lucid - albeit often surprising - answers to universal questions and takes the reader on a fascinating journey of discovery across the boundaries of scientific disciplines. With passion and a keen sense of wonder he draws on philosophy, cultural history and art to formulate his reflections on the mysteries of life. His essays will appeal not only to scientists but to all inquisitive minds, regardless of educational and professional background.

\section{KARGER (Switzerland) www.karger.com}

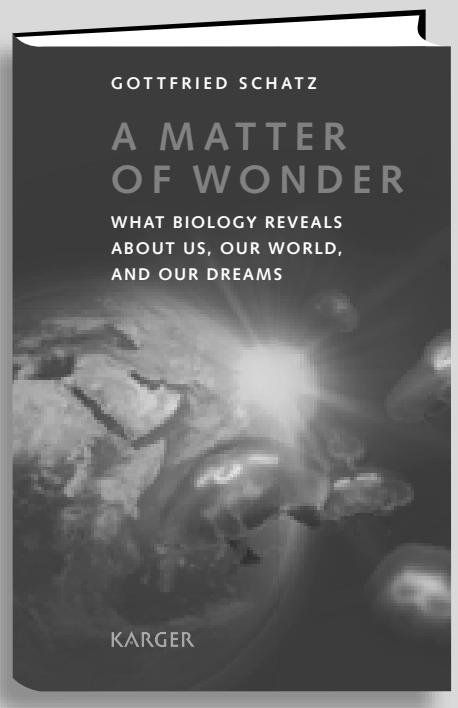

G. Schatz (Basei)

A Matter of Wonder

What Biology Reveals about Us, Our World, and Our Dreams

Translated by A. Shields

XII + 190 p., 2 color fig., hard cover, 2011

CHF 29.-/ EUR 21.50/USD 29.00

ISBN 978-3-8055-9744-9

More information and sample essays at www.karger.com/schatz 


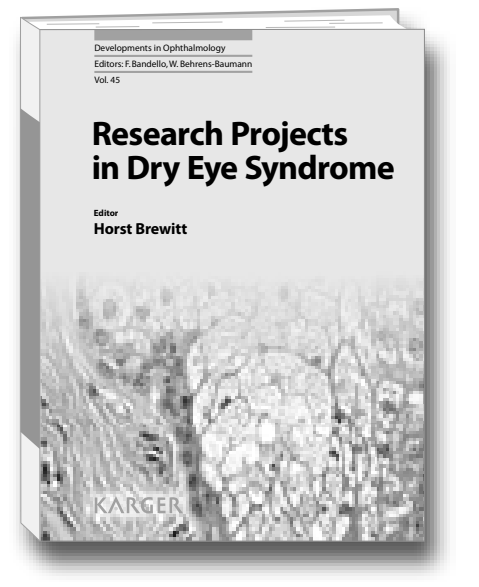

Dry eye is one of the most common disorders encountered in ophthalmological practice. Its symptoms cause considerable discomfort and substantially reduce the patient's quality of life. As it is a complex and multifactorial condition, research investigating dry eye is a matter of great interest all over the world.

In this book, the wide range of current basic and clinical research in dry eye and correlated ocular surface diseases is presented by scientists from Germany, Austria and the USA. These renowned authors provide clear and extensive descriptions of their projects, enabling scientists and clinical ophthalmologists to quickly bring themselves up to date with cutting edge research in this field.

This overview of research into the pathogenesis and clinical treatment of dry eye is a must for all ophthalmologists dealing with this syndrome and looking to increase their knowledge base.

\title{
Research Projects in Dry Eye Syndrome
}

\author{
Editor \\ Horst Brewitt
}

\section{Contents}

\section{Preface: Brewitt, $\boldsymbol{H}$.}

Trefoil Factor Family Peptide 3 at the Ocular Surface. A Promising Therapeutic Candidate for Patients with Dry Eye Syndrome?: Schulze, U.; Sel, S.; Paulsen, F.P. Cationic Amino Acid Transporters and $\beta$ Defensins in Dry Eye Syndrome: Jäger, $\boldsymbol{K}$.; Garreis, F.; Dunse, M.; Paulsen, $F$.

Antimicrobial Peptides as a Major Part of the Innate Immune Defense at the Ocular Surface: Garreis, F.; Gottschalt, M.; Paulsen, F.P.

Regulation of the Inflammatory Component in Chronic Dry Eye Disease by Eye-Associated Lymphoid Tissue (EALT): Knop, $\mathbf{N}$; Knop, E.

Intravital Multidimensional Real-Time Imaging of the Conjunctival Immune System: Gehlsen, U.; Hüttmann, G.; Steven, $P$.

Generation of Two- and Three-Dimensional Lacrimal Gland Constructs: Schrader, S.; Liu, L.; Kasper, K.; Geerling, G.

Midterm Results of Cultivated Autologous and Allogeneic Limbal Epithelial Transplantation in Limbal Stem Cell Deficiency: Pauklin, M.; Fuchsluger, T.A.; Westekemper, H.; Steuhl, K.-P.; Meller, D.
Laser Scanning Confocal Microscopy for Conjunctival Epithelium Imaging: Jürgens, C.; Rath, R.; Giebel, J.; Tost, F.H.W.

Pollen Enzymes Degrade Human Tear Fluid and Conjunctival Cells: An Approach to Understanding Seasonal Non-Allergic Conjunctivitis: Rabensteiner, D.F.; Spreitzhofer, E.; Trummer, G.; Wachswender, C.; Kirchengast, S.; Horwath-Winter, J.; Schmut, 0 .

Towards a New in vitro Model of Dry Eye: The ex vivo Eye Irritation Test: Spöler, F.; Frentz, M.; Schrage, N.F.

The Lid Margin Is an Underestimated Structure for Preservation of Ocular Surface Health and Development of Dry Eye Disease: Knop, E.; Korb, D.R.; Blackie, C.A.; Knop, $\mathbf{N}$.

Diagnostic Markers of Sjögren's Syndrome: Witte, $T$.

Hyperosmolarity of the Tear Film in Dry Eye Syndrome: Messmer, E.M.; Bulgen, M.; Kampik, $A$.

Novel Ocular Lubricant Containing an Intelligent Delivery System: Details of Its Mechanism of Action: Springs, C.

Author Index

Subject Index

www.karger.com/deoph

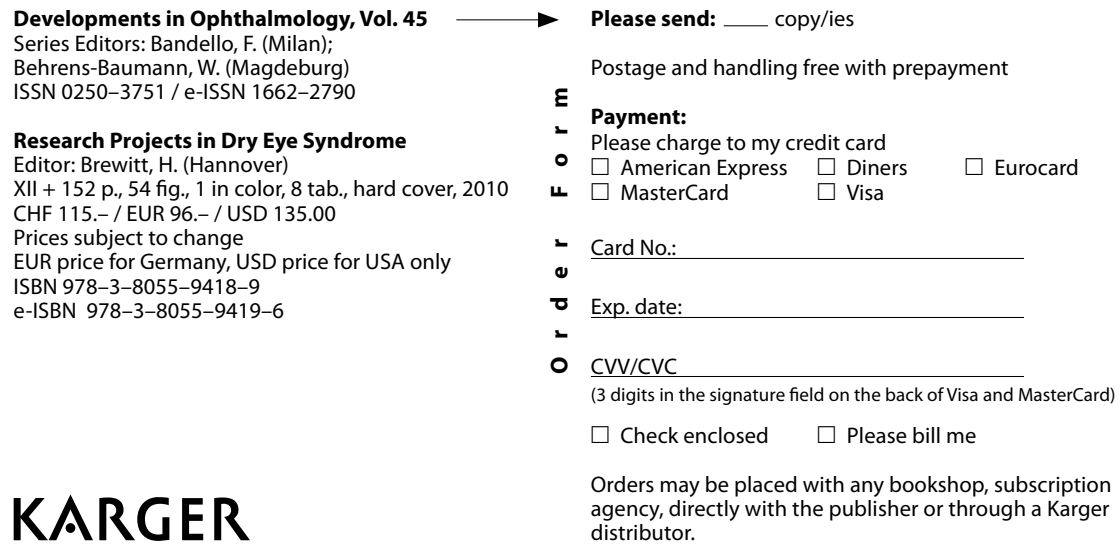

Please send: _ _ copy/ies

Postage and handling free with prepayment

E

Payment

Please charge to my credit card

- $\square$ American Express $\square$ Diners $\square$ Eurocard

$\square$ American Express $\square$ Diners

- Card No.

๑

¿ Exp. date:

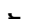

- $\mathrm{CVV} / \mathrm{CVC}$

( 3 digits in the signature field on the back of Visa and MasterCard)

$\square$ Check enclosed $\square$ Please bill me

Orders may be placed with any bookshop, subscription agency, directly with the publisher or through a Karger distributor.

Fax: +41 613061234

S. Karger AG, P.O. Box, CH-4009 Basel (Switzerland) E-Mail orders@karger.ch, www.karger.com

Name/Address: 


\section{Contents}

See the journal website for contents

KARGER Basel $\bullet$ Freiburg $\cdot$ Paris $\bullet$ London $\bullet$ New York $\cdot$ New Delhi $•$ Bangkok Beijing $\cdot$ Tokyo $\cdot$ Kuala Lumpur $\cdot$ Singapore $\bullet$ Sydney 


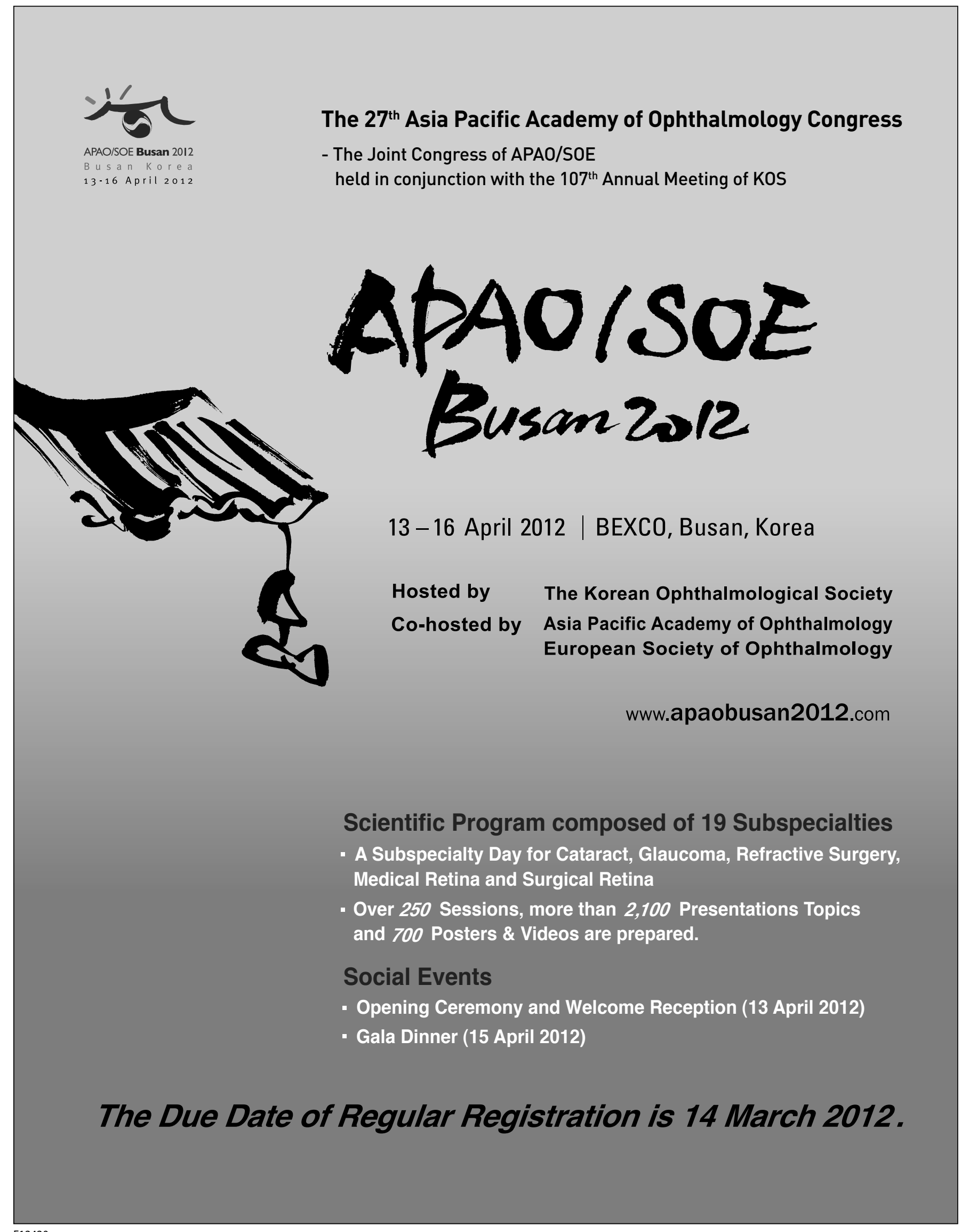




\section{OZURDEX}

\section{(dexamethasone intravitreal implant) $0.7 \mathrm{mg}$}

First-line therapy for the treatment of macular oedema following BRVO and CRVO

or inflammation due to non-infectious intermediate or posterior uveitis

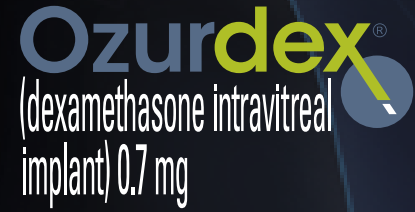

Adverse events should be reported. Reporting forms and information can be found at www.yellowcard.gov.uk. Adverse events should also be reported to Allergan Ltd.UK_Medinfo@allergan.com or 01628494026.
OZURDEX ${ }^{\circ}$ (Dexamethasone 700 micrograms intravitreal implant in applicator) is indicated for the (BRVO) or Central Retinal Vein Occlusion (CRVO) Treatment pererior segment of the eye presenting as non-infectious uveitis Marketing Authoristion Holder. posterior segment of the eye presenting as non-hectious uveth. Marketing Authorisation Holder Date of Preparation: January 2012. UK/0029/2012 


\section{Ophthalmic Research \\ Journal for Translational and Clinical Research}

Impact Factor: 0.847

Official Journal of the

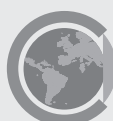

EuroLam
Editors

B. Corcóstegui, Barcelona

D. Pelayes, Buenos Aires

U. Pleyer, Berlin

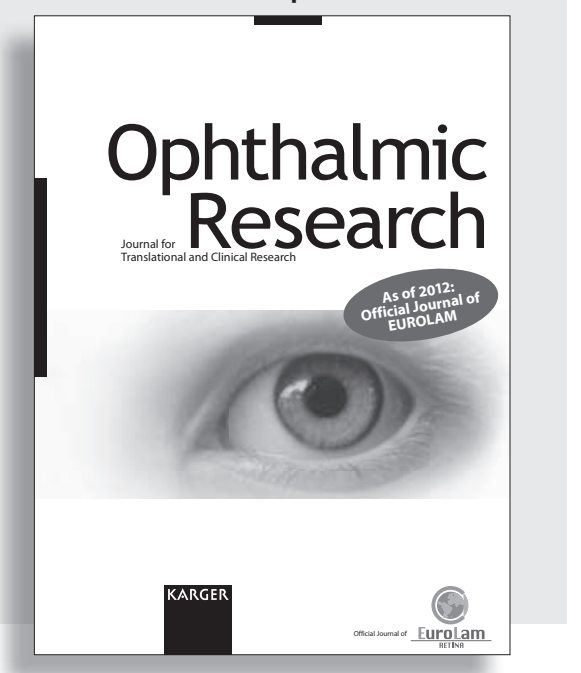

Ophthalmic Research features original papers, reviews and short communications reporting on translational and clinical studies. Authors from throughout the world cover topics on glaucoma, cataract and refractive surgery, retina, uveitis, and other fields in connection with physical, physiologic, pharmacological, biochemical and molecular biological aspects of ophthalmology. This journal provides a record of international clinical research for both researchers and clinicians in ophthalmology.

The journal further offers, at a reasonable price, the possibility of publishing dedicated supplements and abstracts of conferences and symposia. Please consult the managing editor for this.

\section{Selected contributions}

Closure of Sclerotomies after 25- and 23-Gauge Transconjunctival Sutureless Pars

Plana Vitrectomy Evaluated by Optical Coherence Tomography: Sawada, T.;

Kakinoki, M.; Sawada, 0.; Kawamura, H.; Ohji, M. (Otsu)

Intravitreal Ranibizumab and Bevacizumab in Combination with Full-Fluence Verteporfin Therapy and Dexamethasone for Exudative Age-Related Macular Degeneration: Forte, R.; Bonavolontà, P. (Naples); Benayoun, Y.; Adenis, J.P.; Robert, P.-Y. (Limoges)

New Corneal Neovascularization Model in Rabbits for Angiogenesis Research: Campos-Mollo, E. (Alcoy); Pérez-Santonja, J.J. (Alcoy/Alicante); Lledó-Riquelme, M.; Ortega Pastor, E. (Elche); Alió, J.L. (Alicante)

Gene Expression Profile Determination in Rat Retinal Tissue after Ocular Hypertension through Oligo Microarray: Cui, X. (Chongqing); Xu, N.; Liao, W. (Beijing); Xu, J.; Ge, C.; Ye, J. (Chongqing); Liu, X. (Beijing); He, X. (Chongqing)

Chemokine Expression of Intraocular Lymphocytes in Patients with Behçet Uveitis: Kim, T.W.; Chung, H.; Yu, H.G. (Seoul)

A Promising Therapeutic Approach for Treatment of Posterior Uveitis: Recombinant T Cell Receptor Ligand Protects Lewis Rats from Acute and Recurrent Experimental Autoimmune Uveitis: Adamus, G.; Karren, L.J.; Mooney, J.; Burrows, G.G. (Portland, Oreg.)

Physical Changes in Human Meibum with Age as Measured by Infrared Spectroscopy: Borchman, D.; Foulks, G.N.; Yappert, M.C.; Kakar, S.; Podoll, N.; Rychwalski, P.; Schwietz, E. (Louisville, Ky.)

Mechanisms of Retinal Ganglion Cell Injury in Aging and Glaucoma: Chrysostomou, V.; Trounce, I.A.; Crowston, J.G. (East Melbourne, Vic.)
More information at

www.karger.com/ore

- Pay-per-View and Subscriber Access to Full Text

- Full Table of Contents

- Full Editorial Board

- Free Abstracts and Selected Articles

- Online Sample Issue

- Submission/Guidelines for Authors

- Subscription Details

- Free Alert Service

- Online Library Recommendation

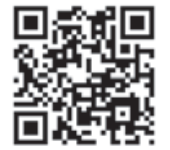

Ophthalmic Research

2012: Volume 47, 48

4 issues per volume

Language: English

ISSN 0030-3747 (print)

ISSN 1423-0259 (online) 


\section{Ophthalmologica}

EURETINA - Review

115 Oxygen Sensing in Retinal Health and Disease

Lange, C.A.K. (London/Freiburg); Bainbridge, J.W.B. (London)

EURETINA - Original Papers

132 Intravitreal Ranibizumab for Macular Edema Secondary to Retinal Vein Occlusion Kim, M.; Yu, S.-Y. (Seoul); Kim, E.-S. (Daejon); Bae, S.H.; Park, J.H.; Yu, H.G.; Kwak, H.-W. (Seoul)

139 Reproducibility and Repeatability of Cirrus ${ }^{\mathrm{TM}}$ HD-OCT Peripapillary Retinal Nerve Fibre Layer Thickness Measurements in Young Normal Subjects

Carpineto, P.; Nubile, M.; Agnifili, L.; Toto, L.; Aharrh-Gnama, A.; Mastropasqua, R.; Di Antonio, L.; Fasanella, V.; Mastropasqua, A. (Chieti)

146 Inflammatory Factors in Major and Macular Branch Retinal Vein Occlusion Noma, H.; Funatsu, H. (Chiba); Mimura, T. (Tokyo); Eguchi, S. (Hakodate); Shimada, K. (Tokyo)

Original Papers

153 Anatomical and Morphometric Study of the Bony Nasolacrimal Canal Using Computed Tomography

Lee, H.; Ha, S.; Lee, Y.; Park, M.; Baek, S. (Seoul)

160 Diurnal and Nocturnal Intraocular Pressure Fluctuations after Trabeculectomy Klink, T. (Würzburg); Praetorius, S. (Wertheim am Main); Leippi, S.; Klink, J.; Grehn, F.J. (Würzburg)

166 Variability in Isopter Position and Fatigue during Semi-Automated Kinetic Perimetry

Nowomiejska, K. (Tübingen/Lublin); Brzozowska, A.; Zarnowski, T. (Lublin); Rejdak, R. (Tübingen/Lublin/Warsaw); Weleber, R.G. (Portland, Oreg.); Schiefer, U. (Tübingen)

Letter to the Editor

173 Response to 'Improved Automated Screening of Diabetic Retinopathy' by Carlos M. Oliveira et al.

Fleming, A.D.; Olson, J.A.; Sharp, P.F.; Goatman, K.A.; Philip, S. (Aberdeen)

174 Reply

Oliveira, C.M. (Coimbra) 